\title{
PHILOSOPHICAL FOUNDATION OF RELIGIOUS COURT COMPETENCE TOWARDS ENCUMBRANCE RIGHT EXECUTION
}

\author{
Abd. Shomad ${ }^{1}$ and Rahadi Wasi Bintoro ${ }^{2}$ \\ ${ }^{1}$ Faculty of Law, Airlangga University, Surabaya - Indonesia \\ E-mail: abd.shomad@fh.unair.ac.id \\ ${ }^{2}$ Faculty of Law, Jenderal Soedirman University, Purwokerto - Indonesia \\ ${ }^{2}$ Candidate Doctor from Doctoral Programme, Airlangga University, Surabaya - Indonesia
}

\begin{abstract}
Religious court as forefront in economic sharia dispute resolution in litigation has not ideal place to perform their duty since there are still regulation conflicts such as implementation of encumbrance right execution which still becomes a domain in district court. As explained, this article discusses philosophical foundation of Religious Court competence to resolve economic sharia issues. In regard to this, conceptual approach, law approach and historical approach are respectively used. Based on the analysis, basic competence of religious court is Islamic personality principle which carries the use of Islamic law elements (sharia principle) in its legal relationship. From the analysis the implication is drawn that as long as a dispute belongs to economic sharia, then it is Religious Court which is competent to handle including court decision.
\end{abstract}

Keywords: law enforcement, economic sharia dispute, absolute competence, court decision implementation

\begin{abstract}
Abstrak
Peradilan Agama sebagai garda terdepan penyelesaian sengketa ekonomi syariah secara litigasi, masih belum mendapatkan tempatnya untuk menyelesaikan sengketa ekonomi syariah secara keseluruhan, karena masih terdapat konflik aturan seperti mengenai pelaksanaan eksekusi hak tanggungan yang masih menjadi domainnya pengadilan negeri. Berdasarkan uraian tersebut, tulisan ini membahas mengenai landasan filosofis kompetensi Peradilan Agama untuk menyelesaikan sengketa ekonomi syariah. Dalam rangka menjawab isu hukum tersebut, maka digunakan pendekatan konseptual, pendekatan perundang-undangan dan pendekatan historis. Berdasarkan analisis, dasar kompetensi peradilan agama adalah prinsip personalitas keislaman, yang mengandung unsur penggunaan hukum islam (prinsip syariah) dalam hubungan hukumnya. Implikasi dari analisis tersebut, maka sepanjang sengketanya adalah sengketa ekonomi syariah, maka hal tersebut menjadi kompetensi Peradilan Agama termasuk pelaksanaan putusan pengadilan.
\end{abstract}

Kata kunci: penegakan hukum, sengketa ekonomi syariah, kompetensi absolut, pelaksanaan putusan pengadilan

\section{Introduction}

Economic sharia system has regained its momentum in early 70 's. ${ }^{1}$ 'he development of

\footnotetext{
Mehmet Asutay, "Conceptualisation Of The Second Best Solution In Overcoming The Social Failure Of Islamic Banking And Finance: Examining The Overpowering Of Homoislamicus By Homoeconomicus", IIUM Journal of Economics and Managemen, Vol. 15, No. 2, 2007, The International Islamic University Malaysia, h. 168; M. Raquibuz Zaman and Hormoz Movassaghi, Islamic Banking A Performance Analysis“, The Journal of Global Business, Vol. 12 No. 22, Spring 2001, h. 38.; Abd. Shomad, “Penerapan prinsip Bagi hasil pada Bank Syariah di jawa
}

economic sharia is criticism ${ }^{2}$ towards the economic system in that era where capitalist and communist economic systems ignored the social prosperity then affected the establishment and the development that can only be reached by certain circle.

Timur”, Masalah-masalah Hukum, Vol. 39 No. 2, 2010, p. 96.

2 John R Presley and John G Sessions, "Islamic Economics: The Emergence of a New Paradm", The Economic Journal, Vol. 104, May 1994, h. 584-585. 
Economic sharia and universal comprehensive teachings of Islam are inseparable, the nature and the wide and flexible scope of Islamic teachings especially on Muamalah (Human Relationship) field is applicable to every community including non-Muslim. ${ }^{3}$ One of the pioneers on running the economic sharia system in Indonesia can be seen from the establishment of Islamic bank (bank Muamalat) as a part of economic sharia system since 1992 till present. ${ }^{4}$ The rapid development of economic sharia in the world ${ }^{5}$, mainly in Indonesia ${ }^{6}$ cannot be separated from the muslim expectation to be kaffah in running its syariat (Islamic law). Moreover, in banking field, conventional banks apply some prohibited matters ruled by syariat such as gambling (maisyir), indefinite/doubtful element (garar), or interest element (riba).

As the consequence of significant development, it is likely to cause dispute between the parties involved in economic sharia activeity. ${ }^{7}$ Thus, it needs a device and institution which are credible and competent in economic sharia field, either judicial or non-judicial institution. $^{8}$

Ahmad, "Penyelesaian Sengketa Ekonomi Syariah di Pengadilan Agama”, Jurnal lus, Vol. 2 No. 6, December 2014, p. 476.

4 Liky Faisal, "Politik Ekonomi Islam Dalam Pembangunan Ekonomi Nasional Di Indonesia", Jurnal Asas, Vol 5 No. 2, 2013, p. 1-2; Nevi Hasnita, "Politik Hukum Ekonomi Syari'ah Di Indonesia", Legitimasi, Vol.1 No. 2, JanuaryJune 2012, p.260; Ari Kurniawan and Abd. Shomad, "The Development of Murabaha in Indonesia Islamic Banks", Rechtsidee, Vol. 3 No. 1, 2006, p. 1

5 Munawar labal And Philip Molyneux, "Thirty Years Of Islamic Banking:History, Performance And Prospects", J. Kau: Islamic Econ., Vol. 19 No. 1, 2006, h. 37; M. Kabir Hassan and Abdel-Hameed M. Bashir, "Determinants of Islamic Banking Profitability", Papers, 10th ERF Annual Conference, Morocco, 2003, web: http://nzibo.com/ IB2/Determinants. pdf, accessed on December 11 2014; Mardani, "Kedudukan Hukum Islam dalam Sistem hukum Nasional", Jurnal Hukum, Vol. 16 No. 2, April 2009, p. 282.

6 Ali Mansyur, "Aspek Hukum Perbankan Syariah dan Implementasinya di Indonesia", Jurnal Dinamika Hukum, Vol. 11, 2011, h. 69; Tim Lindsey, "Between Piety and Prudence: State Syariah and the Regulation of Islamic Banking in Indonesia", Sydney Law Review, Vol. 34 No. 107, 2012, p. 111.

7 Khopiatuziadah, "Kajian Yuridis Penyelesaian Sengketa Perbankan Syariah", Jurnal Legislasi, Vol. 10 No. 3, September 2013, p. 279.

8 Ramlan Yusuf Rangkuti, "Sistem Penyelesaian Sengketa Ekonomi Islam: Instrumen Penting bagi Konsep Ekonomi Islam Mendatang", Asy-Syir'ah-Jurnal Ilmu Syariah dan Hukum, Vol. 45 No. 2, July-December 2011, p. 1432.
According to the decision in Article 49 Law Number 3 Year 2006 on change of Law Number 7 Year 1989 on Religious Courts (then mentioned as Religious (ourts Law) that Religious Courts is competent to investigate, decide, and solve the matter in economic sharia. Economic sharia case is a case emerges from economic sharia dispute which uses the sharia principle on its law relations. Economic sharia activity like in banking points out obligation and rights fulfillment voluntarily between debtor and creditor. Practically, there is a secured goods to fulfill the rights and obligation. The law on security over land and building has been regulated in Law number 4 year 1996 on encumbrance Right Over Land with the Land-RelatedGoods that the execution can be applied through the decision of district court. The District Court meant by the Law here is under the Jurisdiction of Legal Court.

A problem related to the execution of encumbrance rights occurs when the parties finished the law relations (akad) based on sharia principle. On one side, the law relations becomes the competence of Religious Court while on the other side, the execution of encumbrance rights is the competence of district court under the Jurisdiction of Legal Court. This law issue is the discussion of this article, then there is the legal certainty on the execution of encumbrance rights.

\section{Discussion}

The rapid development of economic sharia, as Muslim necessity in Indonesia, finally has influenced the financial industry which brought implication towards the regulation and the organization of its financial institution as well as to the solving dispute mechanism. The Provision of Article 2 on Religious Courts Law regulates that Religious Courts is one of the judicial power actors for the Muslim who seek justice related to a certain case which has been mentioned by the Law. This regulation shows that the Religious court is a court for Muslim for particular case. The cases as mentioned in Article $49 \mathrm{Re}$ ligious court Law has given the limitation for what kind of cases that become its absolute 
authority including marriage, inheritance, last will, bequest, benefaction, zakat, infaq, shodaqoh (charity), and economic sharia. The economic sharia based on the (i) Article 49 is a deed or entrepreneurship activity done according to sharia principle which includes: Sharia Bank, micro-sharia financial institution, sharia insurance, sharia reinsurance, sharia mutual funds, sharia obligation and sharia medium term security, sharia security, sharia financing, sharia pawnshop, and retirement finance of sharia financial institution, and sharia business.

Both regulations has identified the subject and object that become the competence of religious court. Subject is a person, but it needs to be understood that the legal subject as the stakeholder of rights and obligation on law is qualified as person and legal entity. Hence, the subject can be interpreted that it is not only for person but also the legal entity.

The phrase 'believe in Islam' as explained in article 49 Religious court Law includes the people and the legal institution who naturally obey and lay on the Islam rules for the case that become the authority of religious court with the requirement of this Article. This decision highlighted that believing in Islam does not only fit the legal subject, not only human but also the legal institution. Furthermore, this decision encourages the presence of Islamic Law as the base of law relations happened between the subjects. It is important here, that human activity base in the world is Al-Qur'an and As-Sunnah as the system that brings people to the blessed way by Allah SWT. This system based on Islam as "rahmatan lil alamin", meaning that mercy over the world. This shows that Islam does not only concern Muslim people but also for all creatures in the world. Thus, it means that non-Muslim can also do litigation in religious court as long as they obey the Islamic law or in other word as it relates to the law. In the context of legal subject as legal institution, then the phrase of 'believe in Islam' means that the legal institution runs its activities based on Islamic law or based on its legal institution in doing the law relations according to Islamic law. The legal institution that runs the law relations using Islamic law is considered that it has laid on Islamic law. This legal institution can be characterized into 4 categories. First, the legal institution founded based on requirement of Islamic law such as; Amil Zakat Agency, Amil Zakat Institution, Baitul Maal, Nadzir waqaf, etc; Second, legal institution in economic sharia like in sharia banking, sharia pawnshop, and others as mentioned in Article 49 letter h; third, Muslim-owned legal institution; Fourth, other legal institution that possibly run the business or business activity using the sharia principle.

To sum up, the cases of legal subject which become the competence of religious court are First, Muslim; Second, Non-Muslim but he can lay on Islamic law; Third, The legal institutions that run Islamic law-based activities; and Fourth, The legal institution that its article of association is not based on Islamic law but it lays on Islamic law. ${ }^{9}$ All four criteria of legal subject can do litigation in religious court in the cases that have been mentioned in Article 49 Religious court Law.

The use of Islamic Law by legal subjects that becomes the competence of religious court here is mentioned as the principle of Islamic Personality. The principle is based on formal factor without considering the Muslim quality. The principle of Islamic personality according to Yahya Harahap includes the meaning that the party that is subject to religious court is Muslim. ${ }^{10}$ Someone's faith in Islam in this case can be the basis of court authority in religious court. ${ }^{11}$ The personality principle standard of Islam that someone has based when the law relations happened is measured by 2 conditions: first, both parties are Muslim when the law relations happened. Or the second, the law relations is based on Islamic law. Consequently, problems are solved based on Islamic Law. The

- Rahadi Wasi Bintoro, “Hukum Acara Peradilan Agama Dalam Bidang Ekonomi Syariah Berlandasklan Prinsip Peradilan sederhana, Cepat dan Biaya Ringan”, Dissertation, Surabaya, Faculty of Law, 2018, p. 203.

10 Yahya Harahap, Kedudukan. Kewenangan dan Acara Peradilan Agama, Sinar Grafika, Jakarta, 2001, p. 349; Etika Rahmawati, "Telaah terhadap Asas Personalitas Keislaman Dikaitkan dengan Teori Receptio in Complexu", Gloria Yuris, Vol 1 No. 2, 2013, p. 24

11 Jaenal Aripin, Peradilan Agama dalam Bingkai Reformasi Hukum di Indonesia, Jakarta: Kencana, 2008, p. 349. 
principle of Islamic personalities is the distinct characteristics of religious court. This principle emphasized that the investigated cases are those of which legal relations is conducted between legal subject and using the sharia principles.

The application of Islamic personality principle is used to determine whether a dispute becomes the competence of religious courts or not. To apply this principle in Indonesia is not easy due to some regulation conflicts that make it ineffectively implemented in judge's decision like in encumbrance rights implementation.

The encumbrance rights has been regulated in Law Number 4 Year 1996 on encumbrance Right Over Land With The Land-RelatedGoods (then become encumbrance Rights Law). Prior to encumbrance Rights Law existed, the rights imposition over the land as guaranteed debt was applied by mortgage Insurance Agency, because at that time the rights over the land is the legal object in mortgage insurance. Then after the implementation of encumbrance Rights Law, the rights imposition over the land as the guaranteed debt does not apply the mortgage insurance anymore but the encumbrance.

Based on Article 1 Number (1) Law of encumbrance Right, the definition of encumbrance right is right imposed on to right of the land as mentioned in Law Number 5 Year 1960 on Basic Agrarian law. It states that with or without land-related objects, it will be a debt payment mainly to one creditor rather than other creditors. This definition implies that encumbrance right is identical with guarantee rights, which is charged over right of ownership, right to build and/or right to cultivate. It serves main position to particular creditors and swapped the other creditors in case debtor breaches his contract or default in paying his debt. In other words, the holder of first encumbrance right is preferred than other creditors. This case is emphasized more on Article 6 Law of encumbrance Right. ${ }^{12}$

12 Rachmadi Usman, 2011, Hukum Kebendaan, Jakarta: Sinar Grafika, p. 305.
Philosophical foundation of encumbrance Right Law makes creditor easier to execute or sell the objects that have been guaranteed without trial. The definition of execution according to M. Yahya Harahap is execution of court's decision by force with the help of general power if the executing party or defendants unwillingly do it. ${ }^{13}$ The execution is an effort by winning party to gain their rights with the help of judiciary power, force the defeated party to do the decision. According to the explanation above, it implies that only the decision with permanent judiciary power (in kracht van gewijsde) is the decision which cannot be opposed with executable legal effort such as verzet, appeal and cassation.

The execution of encumbrance right is done in case of debtor default (Article 20 Law of encumbrance right). The execution of encumbrance right is the right of the first holder to sell the object in his own power through public auction and pay the debt from the income. Execution can also be done with an agreement by the guarantor and the holder of encumbrance right to sell privately the encumbrance right object to reach the highest price. This execution is only possible after one month since written notification by guarantor/holder of encumbrance right to concerned parties and be announced at least in 2 local newspaper or mass media without objection. The explanation above shows at least three executions in encumbrance right, first, through private selling. The execution of private selling is an easiest way to be conducted under an agreement, so if the debtor is default, the object would be sold in higher price. Consequently it will not harm the debtor (owner of collateral objects) since selling properties through auction will make the price goes down than the normal price. Law gives debtor chance to find buyer by himself before collateral objects are sold in auction. What if the debtor dodge? So it means there is no agreement between creditor and debtor, according to Article 6 Law of encumbrance right, creditor can ask State Assets and Auction Ser-

13 Yahya harahap, 1989, Ruang Lingkup Eksekusi Bidang Perdata, Jakarta: Gramedia, p. 20 
vice Office (KPKNL) to sell it through auction without trial. Second, execution on first encumbrance right authority (parate executie). According to general explanation Number 9 Law of encumbrance right that the idea of "for the sake of justice based on the One God" in encumbrance right certificate aims to make an executorial power in court decision that has been incracht. Therefore, when debtor's default, the collateral objects can be executed based on court decision that has judiciary power along with civil code procedure. In this execution implementation, trial is not needed. Third, the execution based on executoriale titel. This condition emerges when debtor defaults, and the creditor fails in private selling or sell on his own. Creditor in this case can file a request to the court to conduct execution based on encumbrance right certificate which has executoriale titel. This execution is regulated on Art-icle $224 \mathrm{HIR} / 258 \mathrm{R} . \mathrm{Bg}$. Practically, the next pro-cess is the court will do a warning (aan maning) to debtor to pay his debt and its interest rate. If the debtor has paid them, auction would be stopped. Nonetheless, if the debtor does not pay his debt, confiscation would be conducted by bailiff and then court will ask KPKNL to do an auction of encumbrance right object.

The execution through court is the last alternative after private selling or selling under the authority failed. The private selling execution cannot be done if the debtor cannot be met, intentionally dodge or hide after the unperformed loan occur. Thus, private selling of encumbrance right object is not likely to happen. Since one of the requirements of private selling is an agreement between guarantor and holder of encumbrance right. Therefore, Law of encumbrance right provides an authority to the court, which is state court under public court jurisdiction, to conduct the execution.

Encumbrance right surely started by law relationship between law subjects. The problem is when encumbrance right is conducted to a legal relationship within the sharia economic field. On one side, law of encumbrance right gives its competence in state court that in- cluded in public court jurisdiction. On the other side, economic sharia is the competence of religious court. The problem arises when law relationship in economic sharia is sued to religious court and where should be the execution of encumbrance right conducted? Conflict between equal regulations is manifested through law. In that condition, it refers to preference principle which are lex posterior derogat legi priori or lex specialis derogat legi generali.

In order to answer those discourse, the history of religious court is worth examining. Islam and Islamic law always walk side by side. ${ }^{14}$ This happens because Islamic law is a living and inherent law in Muslim life. ${ }^{15}$ The existence of religious court is a sign the more accepted religion in society. Judge position in Islamic jurisdiction is a complement of Islamic syariat (law) implementation, meanwhile its justice is a collective obligation (fardlu kifayah) that something exist and must be done in any circumstances. The existence of Islamic justice has been ups and downs until now. ${ }^{16}$ Islamic justice has existed far before the independence of Indonesia. ${ }^{17}$ Its naturalistic development leads to ideal Islamic justice in the past to get relevant matter and make ideal Islamic justice in the future convenient with Islamic aims as revelation reigion and within the context of national law development.

At first, religious court as Islamic justice had competence in all of human live aspects. As time goes by it decreases and limited in particular field such as family and marriage law, will, grant, endowment (wakaf), and sodaqoh and its

14 M. Daud Ali, “Undang-undang Peradilan Agama”, Panji Masyarakat, Number 634, Date 1-10 January 1990, Jakarta, p. 71.

15 Abd. Somad, "Dinamisasi Penormaan hukum islam", Perspektif, Vol 15 No. 2, 2010, p. 9; Abd. Shomad, "Tajdid Pada Akad Pembiayaan Murabahah di Bank Syariah", Masalah-masalah Hukum, Vol. 40 No. 1, 2011, p. 1.

16 Moh. Sutomo, Syarifah Marwiyah, and Nur Mawaddah Warohmah, "Akar Historis Pengadilan Agama Masa Orde Baru”, YUDISIA, Vol. 7, No. 2, Desember 2016 h. 267; Sumadi Matrais, "Kemandirian Peradilan Agama dalam Perspektif Undang-undang Peradilan Agama”, IUSTUM, No. 1 Vol. 15 January 2008, p. 121-124.

17 Hamiyuddin, "Sejarah Politik Hukum Terhadap Peradilan Agama Di Indonesia", Bilancia, Vol. 10 No. 2, JulyDecember 2016, p. 134. 
just specialized to Muslim, ${ }^{18}$ even it did not cover muamalah field such as economic sharia. Religious court competence, in its development, it extends to implementation of economic sharia, thus, muamalah field in form of economic sharia was added. Economic sharia based on explanation of Article 49 Law religious court is business activity conducted based on sharia principle. Article 26 Paragraph (2) Law Number 21 year 2008 govern sharia principle becomes the basic operational of product and service in sharia finance institution stated by Indonesian Ulema Council (MUI) and then stipulated in Indonesian Bank regulation. The definition of sharia principle is emphasized more in Indonesian Bank regulation Number 11/15/PBI/2009 on money market among banks based on sharia principle. It is considered as Islamic law principle in banking activity based on decree issued by Indonesian Ulema Council.

Any issues of religious court competences including marriage, inheritance, will, wakaf, zakat, infaq, shadaqoh, grant (hibah) until economic sharia problem are attached matters in Muslim life. The extended religious court competence is inevitable regarding symmetrical correlation between society development and law. Therefore, there will be no gap between problem and solution.

The extended competence includes muamalah field in form of economic sharia in 2006 through Law Number 3 year 2006. The philosophical foundation is that religious court as Islamic justice must fulfill society needs over dispute settlement of economic sharia. Hence, it can be understood that law of encumbrance right made in 1996 had not yet accommodated society needs over sharia principle implementation in economic activity. Consequently, they gave the execution of encumbrance right to state court under public court jurisdiction. Especially in banking field, economic sharia term had been legally used since 1992 through Law Number 7 Year 1992 on Banking and Government Regulation Number 72 Year 1992 on Bank based on Profit Sharing Principle. Economic sha-

18 See Law Number. 7 Year 1989 on Religious Court ria term used was "profit sharing principle". In 1998 through Law Number 10 Year 1998 change of Law Number 7 Year 1992 on banking that Islamic banking which called "profit sharingbased bank" was clearly claimed in those law to be called "syariah-based bank". The existence of economic sharia in banking field grew stronger due to Law Number 21 Year 2008 on Sharia banking.

Regarding regulation conflict about execution competence of encumbrance right between law of religious court and law of encumbrance right, it actually can be solved with lex specialis derogat legi generali principle. Religious court as justice applying Islamic law with its Islamic personality principle can be placed as lex specialis. Meanwhile law of encumbrance right providing general rule becomes lex generali. Thus, execution of encumbrance right, even fiduciary execution will be the competence of religious court as long as its law based on sharia principle.

\section{Conclusion}

Islamic Personality principle is a philosophical foundation of religious court's competence to execute encumbrance right as long as the law based on sharia principle. Islamic personality principles emphasize on problems of law subject that become religious court's competence are: first, Islamic people (Muslim); second, Non-Muslim but they obey the Islamic law; third, law institution of which article of association is based on Islamic law; and Fourth, Law institution that their article of association does not refer to Islamic law but they obey the Islamic law.

\section{References}

Ahmad. "Penyelesaian Sengketa Ekonomi Syariah di Pengadilan Agama”. Jurnal lus. Vol 2 No. 6. December 2014. Pp. 476-488;

Ali, M. Daud. "Undang-undang Peradilan Agama”. Panji Masyarakat. Nomor 634. Tanggal 1-10 Januari 1990. Jakarta;

Aripin, Jaenal. 2008. Peradilan Agama dalam Bingkai Reformasi Hukum di Indonesia. Jakarta: Kencana; 
Asutay, Mehmet. "Conceptualisation Of The Second Best Solution In Overcoming The Social Failure Of Islamic Banking And Finance: Examining The Overpowering Of Homolslamicus By Homoeconomicus". IIUM Journal of Economics and Managemen. Vol. 15. No. 2. 2007. Pp. 167195;

Faisal, Liky. "Politik Ekonomi Islam Dalam Pembangunan Ekonomi Nasional Di Indonesia”. Jurnal Asas. Vol 5 No. 2. 2013. Pp. 1-11;

Hamiyuddin. "Sejarah Politik Hukum Terhadap Peradilan Agama Di Indonesia". Bilancia. Vol. 10 No. 2. July - December 2016. Pp. 134-152;

Harahap, Yahya. 1989. Ruang Lingkup Eksekusi Bidang Perdata. Jakarta: Gramedia; 2001. Kedudukan. Kewenangan dan Acara Peradilan Agama. Jakarta: Sinar Grafika;

Hasnita, Nevi. “Politik Hukum Ekonomi Syari'ah Di Indonesia”. Legitimasi. Vol.1 No. 2. January-June 2012. Pp. 108-124;

Hassan, M. Kabir and Abdel-Hameed M. Bashir. 2003. "Determinants of Islamic Banking Profitability". Papers. 10th ERF Annual Conference. Morocco. Tersedia di: http://nzibo.com/IB2/Determinants. pdf. retrieved on December 11 2014;

Iqbal, Munawar And Philip Molyneux. "Thirty Years Of Islamic Banking:History. Performance And Prospects". J.Kau: Islamic Econ.. Vol. 19. No. 1. 2006. Pp. 37-39;

Khopiatuziadah. "Kajian Yuridis Penyelesaian Sengketa Perbankan Syariah". Jurnal Legislasi. Vol. 10 No. 3. September 2013. Pp. 279-290;

Kurniawan, Ari and Abd. Shomad. "The Development of Murabaha in Indonesia Islamic Banks". Rechtsidee. Vol. 3 No. 1. 2006. Pp. 1-16. DOI: 10.21070/jihr.v3i1.153;

Lindsey, Tim. "Between Piety and Prudence: State Syariah and the Regulation of Islamic Banking in Indonesia". Sydney Law Review. Vol. 34 No. 107. 2012. Pp. 107127;

Mansyur, Ali. "Aspek Hukum Perbankan Syariah dan Implementasinya di Indonesia". Jur- nal Dinamika Hukum. Vol 11 2011. Pp. 6775. DOI: 10.20884/1.jdh.2011.11. Edsus. 263

Mardani. "Kedudukan Hukum Islam dalam Sistem hukum Nasional". Jurnal Hukum. Vol. 16 No. 2. April 2009. h. 267-287. DOI: 10.20885/iustum.vol16.iss2.art7

Matrais, Sumadi. "Kemandirian Peradilan Agama dalam Perspektif Undang-undang Peradilan Agama". IUSTUM. No. 1 Vol. 15 January 2008. h. 121-144. DOI: 10.20885/ iustum.vol15.iss1.art6;

Presley, John R and John G Sessions. "Islamic Economics: The Emergence of a New Paradm". The Economic Journal. Vol. 104. May 1994. Pp. 584-596.

Rahmawati, Etika. "Telaah terhadap Asas Personalitas Keislaman Dikaitkan dengan Teori Receptio in Complexu”. Gloria Yuris. Vol. 1 No. 2. 2013;

Rangkuti, Ramlan Yusuf. "Sistem Penyelesaian Sengketa Ekonomi Islam: Instrumen Penting bagi Konsep Ekonomi Islam Mendatang". Asy-Syir'ah-Jurnal Ilmu Syariah dan Hukum. Vol. 45 No. 2. July-December 2011. Pp. 1431-1449.

Shomad, Abd. "Penerapan prinsip Bagi hasil pada Bank Syariah di jawa Timur". Masalahmasalah Hukum. Vol. 39 No. 2. 2010. Pp. 96-105. DOI: $10.14710 / \mathrm{mmh} \cdot 39.2 .2010$. 96-105;

"Dinamisasi Penormaan hukum islam". Perspektif. Vol 15 No. 2. 2010. Pp. 99122;

"Tajdid Pada Akad Pembiayaan Murabahah di Bank Syariah". Masalah-masalah Hukum. Vol. 40 No. 1. 2011. Pp. 1-9. DOI: 10.14710/mmh.40.1.2011.1-9;

Sutomo, Moh. Syarifah Marwiyah. and Nur Mawaddah Warohmah. "Akar Historis Pengadilan Agama Masa Orde Baru". YUDISIA. Vol. 7. No. 2. Dec 2016. Pp. 267-284;

Usman, Rachmadi. 2011. Hukum Kebendaan. Jakarta: Sinar Grafika;

Zaman, M. Raquibuz and Hormoz Movassaghi. "Islamic Banking A Performance Analysis". The Journal of Global Business. Vol. 12. No. 22. Spring 2001. Pp. 31-38. 